\title{
Gerakan Populis sebagai Tren Global: Dari Amerika Latin sampai Occupy Movement
}

\author{
Arif Darmawan ${ }^{1}$
}

\begin{abstract}
The gap in Latin American countries is a fertile ground for the emergence of a populist movement, so that populism is not considered as a deviation, but become a rational alternative to address the problems rooted in the failure of the nation-building process. The existence of populism in Latin America indirectly also has an influence on the movement rooted in populism in the global sphere. This paper will analyze the close connection between the recent wave of populism in the international world by looking at the historical roots of how populism developed in Latin America and its effect on the "Occupy Movement" movement phenomenon in order to know how the pattern of populist movements in the global realm. This article will begin by understanding the clear definition of what is populism, then the roots of populist history in Latin America, and how it relates to the emergence of the Occupy Movement as a new form of populist movement that is becoming a global tren.
\end{abstract}

Keywords: populism, Latin America, Occupy Movement

\begin{abstract}
Abstrak
Kesenjangan yang terjadi di negara-negara Amerika Latin memang menjadi lahan subur munculnya gerakan populis, sehingga populisme tidak dianggap sebagai sebuah penyimpangan, tetapi menjadi satu bentuk alternatif rasional untuk mengatasi permasalahan yang berakar pada kegagalan proses nation-building. Keberadaan populisme di Amerika Latin ini secara tidak langsung juga mempunyai pengaruh terhadap gerakan yang berakar pada populisme di ranah global. Makalah ini akan menganalisis keterkaitan yang erat antara gelombang populisme yang akhir-akhir ini terjadi di dunia internasional dengan melihat akar sejarah bagaimana populisme berkembang di Amerika Latin serta pengaruhnya terhadap fenomena pergerakan Occupy Movement dengan tujuan untuk mengetahui bagaimana pola gerakan populisme di ranah global. Artikel ini akan mengawali dengan memahami definisi yang jelas mengenai apa itu populisme, kemudian akar sejarah populisme di Amerika Latin, dan bagaimana keterkaitannya dengan kemunculan Occupy Movement sebagai bentuk gerakan populis baru yang menjadi tren global.
\end{abstract}

Kata kunci: populisme; Amerika Latin; Occupy Movement

\section{Pendahuluan}

Kebangkitan politik populis dalam 15 tahun terakhir, yang sangat terlihat di kawasan Amerika Latin, Eropa, dan beberapa kawasan di dunia menjadi sebuah fenomena global dan bisa dibaca sebagai sebuah tanda dan respon terhadap krisis kronis dalam demokrasi liberal. Di satu sisi gerakan politik populis tersebut menarik perhatian masyarakat sipil dan mengkampanyekan adanya pembangkangan sipil karena dengan kondisi demokrasi yang

\footnotetext{
${ }^{1}$ Dosen Jurusan HI, FISIP, Universitas Jenderal Soedirman
}

ada menjanjikan pengembalian kekuasaan kepada rakyat serta memaksa sistem politik untuk memenuhi tuntutan-tuntutan mereka. Di sisi lain. populisme juga sering dianggap membahayakan demokrasi dengan adanya janji -janji palsu, ketidakpedulian dengan permasalahan manajemen ekonomi, serta secara keseluruhan tidak ada penghormatan terhadap konstitusionalisme dan prosedur demokrasi (Stravrakakis, 2016: 52). 
Gerakan populis yang sedang menjadi tren pada saat ini tidak hanya terikat pada munculnya figur tertentu yang menjadi tokoh politik di suatu kawasan, tetapi juga menjadi satu bentuk gerakan transnasional yang menjadi tren global dalam bentuk protes dan mobilisasi massa, melibatkan teknologi informasi (cyberpolitics), yang arah tujuannya adalah untuk melawan ketimpangan global. Gerakan populis global ini tidak hanya sekedar gerakan reaksioner yang berada dalam satu kawasan tertentu, tetapi merupakan sebuah gerakan yang dekat dengan pusat kekuasaan global, dan diinisiasi oleh kelompok terpelajar, aktivis kreatif, dan populasi urban (Pelfini, dalam Lenger \& Schumacher, 2015: 199).

Makalah ini akan membahas mengenai keterkaitan antara gerakan populisme di kawasan Amerika Latin dan gerakan Occupy Movement, dengan mengidentifikasi kesamaan, tujuan, dan semangat yang ada diantara kedua gerakan ini. Makalah ini akan dimulai dengan mencari definisi mengenai populisme itu sendiri, kemudian melacak bagaimana perkembangan populisme di Amerika Latin, dilanjutkan dengan menganalisis mengenai Occupy Movement dan keterkaitannya dengan gerakan populis di Amerika Latin.

Makalah ini disusun menggunakan metode penelitian kualitatif. Artinya, data yang dikumpulkan merupakan data yang berasal dari dokumen resmi, catatan lapangan, dokumen pribadi, dan dokumen lain yang mendukung. Dengan demikian, penelitian ini akan menggambarkan realitas empirik di balik fenomena secara mendalam, rinci, dan tuntas. Sumber data utama adalah buku, jurnal atau tulisan ilmiah, dan laporan penelitian yang terkait dengan fenomena populisme di wilayah Amerika Latin maupun di ranah global.

\section{Pembahasan}

\section{Definisi Populisme}

Ada berbagai macam definisi populisme, walaupun tidak menghasilkan kesepakatan bersama dalam mendefinisikannya secara seragam. Mudde (2004: 542-563) memberikan penjelasan mengenai populisme sebagai posisi politik yang menempatkan masyarakat kebanyakan atau rakyat biasa berhadapan (vis-a-vis) secara antagonistik dengan elit politik yang dianggap korup, kemudian politik merupakan satu bentuk ekspresi keinginan secara umum masyarakat kebanyakan. Populisme cenderung menarik perhatian 'rakyat' untuk melawan struktur kekuasaaan yang sudah mapan serta pemikiran dan nilai-nilai dominan dalam masyarakat, yang mana didalamnya termasuk ajakan untuk melakukan revolusi atas nama rakyat melawan para elit (Pelfini, 2015: 201).

Beberapa pemikiran lain melihat populisme sebagai ekspresi politik yang memiliki beberapa elemen, antara lain: antikemapanan (dalam arti mewakili ekspresi kelompok yang merasa termajinalkan), kemudian adanya otoritas kepemimpinan yang menonjol lewat karisma atau figur personal 
atau melalui pesan-pesan yang tendensius dan apokaliptik, lalu adanya perasaan in-group yang kuat, dan menunjukkan adanya posisi antagonistik antara dua pihak, yang mana garis pembatasnya bisa berdasarkan status ekonomi, penduduk asli dan migran, atau yang bersifat SARA. Dalam kamus sosiologi, populisme diartikan sebagai "suatu bentuk khas retorika politik yang menganggap keutamaan dan keabsahan politik terletak pada rakyat, memandang kelompok elit dominan sebagai pihak yang korup, dan sasaran-sasaran politik akan dicapai paling ideal adalah melalui hubungan langsung antara pemerintah dan rakyat, tanpa perantara lembaga-lembaga politik yang ada" (Abercombrie, et al., 1998). Canovan (1999: 4-5) menyatakan bahwa populis mengklaim adanya legitimasi yang mereka miliki bahwa mereka mewakili rakyat serta mewakili kedaulatan demokratik, tidak sekedar mewakili kepentingan kelas tertentu. Para akademisi pada akhirnya bersepakat bahwa pemahaman mengenai apa itu populisme menjadi sebuah konsep yang dipertarungkan (contested concept), karena tidak ada konsensus bersama mengenai pemahaman mengenai populisme, walaupun dari semua definisi yang ada sebenarnya ada persamaan yang bisa ditarik.

Berdasarkan berbagai pemahaman mengenai populisme, Canovan (1981) membagi populisme menjadi tiga jenis. Pertama, populisme wong cilik, yang berorientasi pada petani, borjuis kecil, kaum buruh, dan selalu antagonistik terhadap elit politik dan kaum borjuasi besar yang dianggap selalu punya skenario untuk menindas rakyat kebanyakan atau wong cilik. Populisme jenis pertama ini tidak sepakat dengan ide-ide kemajuan yang merupakan produk kapitalisme yang sangat ditentangnya. Populisme kedua adalah populisme otoriter, yang mengharapkan munculnya para pemimpin karismatik dari sebuah proses demokratis. Pemimpin yang lahir dari populisme jenis ini bisa mengarah pada otoritarianisme dan totaliter jika lama berkuasa. Jenis populisme ketiga adalah populisme revolusioner, yang merupakan perwujudan pemikiran kolektif menolak segala macam bentuk elitisme dan ide-ide tentang kemajuan, serta menggalang ide-ide pembaruan yang revolusioner. Tatanan dan institusi politik dinilai tidak lebih dari perwujudan dominasi elit atas rakyat sehingga harus dirubah dan direbut melalui dukungan penuh pada pemimpin revolusioner yang dianggap mewakili kepentingan rakyat banyak.

\section{Populisme di Amerika Latin: Akar Sejarah \& Pengaruh di Ranah Global}

Dalam politik di Amerika Latin, istilah populist menjadi sebuah istilah yang umum digunakan oleh hampir tiap pemerintahan di wilayah tersebut, bahkan yang berkarakter neoliberal pada tahun 1990-an (Grigera, 2017: 2). Oleh karena itu, Amerika Latin secara historis dianggap merupakan tempat akar 
pertumbuhan populisme di abad ke-20 muncul dan menjadi kunci pengaruh bagi tumbuhnya 'tipe ideal' gerakan populis, yang ditunjukkan dengan munculnya pemimpin karismatik yang memiliki hubungan langsung yang kuat dengan para pengikutnya (Stavrakakis, 2016: 52).

Menurut Grigera (2017: 2-11), cecara garis besar, ada tiga gelombang populisme yang muncul di Amerika Latin. Pertama adalah pada era 1950-an dan 1960-an, yang didasarkan pada analisis pemerintahan pascaperang tahun 1930-an, ketika muncul pemimpin karismatik seperti Peron (Argentina), Vargas (Brazil), dan Cardenas (Mexico). Interpretasi yang menggambarkan populisme gelombang pertama di Amerika Latin ini mempunyai karakteristik sebagai satu bentuk fenomena politik-ideologis, terkait dengan bagaimana memanipulasi massa yang ada dan tidak terdidik ( available \& uneducated) oleh sekelompok elit politik yang disebut sebagai caudillo (pemimpin). Sisi personal seorang pemimpin (personalism) lebih ditonjolkan dibandingkan kelembagaan (institutionalism). Munculnya Peronism di Argentina merupakan contoh nyata gelombang populisme pertama ini.

Gelombang populisme kedua adalah apa yang disebut sebagai Pink Tide populism atau neoliberal populism yang terjadi pada dekade 1990-an, dan bisa tercermin pada kepemimpinan Menem (Argentina), Fujimori (Peru), dan Collor de Mello (Brazil).
Populisme neoliberal ini berusaha untuk menggabungkan populisme dengan neoliberalisme, seperti yang dilakukan oleh Carlos Menem di Argentina dan Alan Garcia serta Alberto Fujimori di Peru. Pemerintahan mereka dianggap sebagai populis dikarenakan walaupun mereka menerapkan reformasi berdasarkan Washington Consensus, gaya politik mereka kental dengan upaya merebut hati rakyatnya melalui jargon nasionalisme dan janji-janji akan adanya redistribusi ekonomi.

Gelombang ketiga adalah apa yang disebut sebagai neo-populism, yang tercermin dalam beberapa pemerintahan yang muncul sebagai akibat dari mobilisasi sosial melawan neoliberalisme pada dekade tahun 2000-an, seperti misalnya pemerintahan Kirchner (Argentina), Lula (Brazil), dan Chavez (Venezuela). Neopopulisme ini muncul sebagai reaksi terhadap krisis ekonomi dan politik yang timbul dari kegagalan neoliberalisme di kawasan tersebut.

Menurut Pelfini (2015: 203-204), gelombang populis di Amerika Latin kontemporer merupakan perwujudan kebangkitan Kiri Baru dan memperlihatkan pengaruh kuat tradisi sejarah populisme di kawasan ini, yaitu ada kesamaan bahwa populisme muncul sangat terkait dengan konstelasi internasional yang sedang mengalami krisis ekonomi global. Populisme yang muncul saat ini di Amerika Latin isu yang diangkat masih relatif sama, yaitu mengenai kesenjangan ekonomi. Perbedaannya 
adalah gerakan populisme kontemporer di Amerika Latin dipimpin oleh koalisi sektor kelas menengah yang bekerja sama dengan organisasi kelas pekerja yang mempunyai sejarah panjang dalam berjuang. Mereka mempunyai kepentingan bersama terkait dengan mengkampanyekan kebijakan sosial yang universal dan kebijakan relokasi ekonomi dalam rangka untuk meningkatkan kondisi kehidupan dan memperoleh kekuasaan bagi kelas yang lebih rendah.

Terkait dengan pengaruh populisme kontemporer di Amerika Latin dalam ranah global, paling tidak bisa dilihat pada tiga faktor, yaitu: bagaimana cara menghadapi krisis yang terjadi, klaim akan demokrasi yang lebih nyata, dan eksplorasi terhadap ekonomi dan politik posneoliberal (Pelfini, 2015: 204). Gerakan di Amerika Latin pada awalnya lebih membatasi pada cakupan wilayah nasional atau regional, tapi dalam perkembangannya protes yang dilakukan mengarah pada representasi kekuatan finansial global, tidak sekedar pemerintahan nasional (Pelfini, 2011). Sebagai contoh adalah gerakan Indignados di Meksiko yang pada awalnya merupakan gerakan memprotes pemerintah Meksiko dalam menangani persoalan peredaran obat bius di negara tersebut, berubah menjadi gerakan besar lintas negara yang memprotes kesenjangan ekonomi dan kemiskinan global, sebuah permasalahan laten yang mendera kawasan Amerika Latin sejak lama.
Sementara itu, konteks krisis keuangan global yang terjadi pada tahun 2008 sangat relevan dengan kondisi Amerika Latin selama ini. Sebagai contoh, krisis keuangan tersebut dianggap sebagai satu bentuk kegagalan neoliberalisme, sebuah permasalahan yang sejak lama dialami oleh beberapa negara seperti Argentina, Bolivia, Ekuador, dan Venezuela pada awal dekade 2000-an. Bisa dikatakan neoliberalisme melalui Washington Consensus terlebih dahulu mengalami kegagalan di Amerika Latin sebelum akhirnya berpengaruh terhadap krisis ekonomi global yang terjadi. Hal ini berpengaruh juga terhadap gerakan populisme global, di mana isu yang diangkat relatif sama dengan isu-isu yang ada sejak lama di Amerika Latin, dan semakin menguat pasca-krisis global tersebut.

Terkait dengan klaim atas demokrasi yang lebih nyata, populisme global juga mempunyai akar yang sama dengan populisme di Amerika Latin kontemporer (Pelfini, 2015: 205-206). Keduanya memperlihatkan adanya kontrak sosial yang terputus antara masyarakat dengan perwakilannya. Kaum populis, baik itu di aras regional Amerika Latin maupun di aras global, melihat bahwa krisis yang terjadi disebabkan oleh adanya keterputusan kontrak sosial yang merupakan tanggungjawab elit politik dan ekonomi. Di Amerika Latin, kaum populis melihat perilaku oligarkhi lokal dan kaum industrialis yang hanya mewakili minoritas dari populasi, sementara di ranah global kaum populis menyoroti kaum kapitalis 
neoliberal yang juga dianggap hanya mewakili minoritas elit di dunia.

\section{“Occupy Movement” sebagai Bentuk Gerakan Populis Global di Abad-21}

Occupy Wall Street (OWS), atau secara luas sering disebut sebagai Occupy Movement, merupakan sebuah gerakan protes yang diawali oleh sekelompok orang pada tanggal 17 September 2011 di Zuccotti Park, di dekat distrik keuangan Wall Street, New York. Para aktivis tersebut menyuarakan kesenjangan ekonomi dan sosial, pengangguran, korupsi, dan keserakahan pemerintah serta elit politik dan pemilik perusahaan besar. Slogan yang dikampanyekan adalah 'We are the 99\%' yang menggambarkan bahwa kemakmuran hanya dimiliki oleh kurang dari $1 \%$ elit dari keseluruhan penduduk Amerika Serikat. Gerakan ini dengan cepat berubah menjadi suatu gerakan global dengan membawa isu yang sama, yaitu kesenjangan sosial, kemiskinan global, dan keserakahan kaum pemilik modal yang diklaim hanya $1 \%$ dari keseluruhan jumlah penduduk dunia.

Calhoun (2013: 27-28) menyatakan bahwa Occupy Movement merupakan bagian dari gelombang mobilisasi internasional, dan tidak eksklusif berasal dari Amerika Serikat saja. Menurut Calhoun, krisis ekonomi global pada tahun 2008 membuka mata banyak orang di berbagai kawasan penjuru dunia bahwa ada sesuatu yang berjalan tidak semestinya dalam ekonomi global yang menciptakan kesenjangan ekonomi yang semakin lebar, tidak hanya di level lokal ataupun nasional tetapi juga di level global. Walaupun secara nyata dimulai dari New York, tetapi menurut Calhoun, sebenarnya mobilisasi massa sejenis untuk memprotes kondisi yang ada sudah muncul di negara-negara Eropa. Peran media visual menyebarkan berita dan foto-foto pergerakan tersebut berperan besar dalam mempersatukan berbagai macam movement dalam satu barisan gerakan yang membawa semangat 'we are the 99\%' yang awalnya disuarakan di Wall Street, New York.

Occupy Movement merupakan sebuah bentuk gerakan populis terbesar di abad ke-2. Semangat yang dibawa gerakan ini melalui semboyan 'we are the 99\%' menjadikannya semboyan perlawanan global terhadap kesenjangan ekonomi dan kemiskinan global. Kesuksesan gerakan ini menjadi fenomena global tidak terlepas dari ekspresi atau semangat yang dibawakan, yang bisa dikatakan sebagai satu bentuk 'open-source populism' (Lowndes \& Barren, 2011). Opensource populism yang dimaksud di sini adalah, populisme yang dibawa oleh gerakan ini memiliki persamaan dan perbedaan dengan populisme yang telah ada, terutama yang muncul di Amerika Latin. Occupy Movement banyak mengambil gaya pergerakan dari $\mathrm{New}$ Left, yang secara substantif menjadi warna gerakan pada dekade 1930-an ketika isu kesenjangan ekonomi menjadi isu utama.

Dari segi wacana yang disuarakan, ada kesamaan dengan populisme di Amerika Latin, 
yaitu semangat antagonisme terhadap elit ekonomi-politik yang dituduh menjadi penyebab semakin lebarnya kesenjangan ekonomi yang terjadi. elit minoritas tersebut dianggap paling bersalah atas kondisi yang terjadi dan masyarakat banyak yang menjadi mayoritas selalu dianggap tidak berdosa dan menjadi korban. Dari segi mobilisasi massa, Occupy Movement menurut Pelfini (2015: 207) menunjukkan ciri khas demokrasi radikal yang sifatnya mobilisasinya horizontal, tidak vertikal seperti populisme dan cenderung bersifat spontan. Tipe mobilisasi seperti ini bisa dilaksanakan oleh sekelompok orang atau kelompok karismatik, berbeda dengan di Amerika Latin yang pergerakan populisme-nya diwarnai oleh peran besar individual yang disebut Caudillo.

Kemunculan Occupy Movement juga berada dalam momen yang sama seperti di Amerika Latin, yaitu ketika ada nuansa jarak antara masyarakat dengan elit politik dan ekonomi yang ternyata menyebabkan adanya permasalahan, dalam hal ini adalah krisis. Konteks di Amerika Latin memunculkan gerakan populis yang menghasilkan rezim pemerintahan untuk merespon krisis, perbedaannya dalam konteks global, Oсcupy Movement menjadi satu bentuk gerakan populis yang tidak berubah menjadi satu bentuk rezim, tetapi menjadi satu bentuk gerakan massif yang cair, atau dengan kata lain mudah berubah bentuk, walaupun tetap membawa ciri khas yang ada dalam populisme.

\section{Penutup}

Ada perbedaan cukup mendasar ketika mempelajari populisme yang berkembang di Amerika Latin dengan populisme di ranah global, terutama yang diwakili oleh kemunculan Occupy Movement. Salah satu perbedaan terbesarnya adalah, populisme di Amerika Latin dalam perkembangan sejarahnya sangat mempengaruhi kondisi di wilayah tersebut, karena populisme Amerika Latin berujung pada terbentuknya rezim pemerintahan dengan gaya masing-masing, mulai dari otoriter sampai dengan neoliberal. Perbedaan lain adalah dari sisi mobilisasi massa. Di Amerika Latin, mobilisasi massa bersifat vertikal, sedangkan Occupy Movement lebih bersifat horizontal. Tetapi jika melihat konteks dan isu yang diangkat, maka jelas ada keterkaitan kuat antara populisme Amerika Latin dengan Occupy Movement karena isu utama yang diangkat adalah sama, yang akarnya adalah kesenjangan ekonomi. Antagonisme terhadap elit juga menjadi ciri khas yang tetap ada, yang mana klaim mewakili suara rakyat banyak yang dirugikan melawan kerakusan elit yang selalu menjadi pihak yang bersalah. Dengan berbagai perbedaan dan persamaan di atas, satu hal yang bisa ditarik sebagai kesimpulan akhir adalah gerakan populis global yang ditandai dengan kemunculan Occupy Movement secara tidak langsung dipengaruhi oleh populisme yang mengakar di Amerika Latin. 


\section{Daftar Pustaka}

Aslanidis, Paris, (2015). Is Populism an Ideology? A Refutation \& a New Perspective. Political Studies, p. 1-17. Political Studies Association. DOI: 10.1111/1467-9248.12224

Blair, Taylor (2013). From Alterglobalization to Occupy Wall Street: Neoaanarchism and the new spirit of the left, City: analysis of urban trends, culture, theory, policy, action, 17:6, 729-747. DOI: 10.1080/13604813.2013.849127.

Canovan, Margaret. (1981). Populism. New York: Junction Books.

Canovan, Margaret. (1999). Trust the people! Populism and the two faces of democracy. Political Studies 47(1): 2-16.

Canovan, Margaret. (2002). Taking politics to the people: Populism as the ideology of democracy. dalam Democracies and the populist challenge, ed. Yves Me'ny and Yves Surel, 25-44.Basingstoke: Palgrave.

Chomsky, Noam. (2012). Ocсupy. New York: Penguin Books.

Conniff, Michael. (1999). Populism in Latin America. Tuscaloosa: University of Alabama Press.

Calhoun, Blair (2013). Occupy Wall Street in Perspective. The British Journal of Sociology Vol. 64 Issue 1, p. 26-38.

Grigera, Juan, (2017). Populism in Latin America: Old and New Populisms in Argentina \& Brazil. International Political Science Review, p. 1-15. Sage Publication, DOI: 10.1177/0192512117701510.

Gitlin, Todd, (2012). Occupy Nation: The Roots, the Spirit, and the Promise of Occupy Wall Street .New York: ITBooks.

Laclau, Ernesto. (2005). On populist reason. London: Verso.

Mudde, Cas (2004). The Populist Zeitgeist. Government and Opposition 39: 541-63.

Mudde, Cas, and Cristóbal Rovira Kaltwasser. (2013). Exclusionary vs. Inclusionary Populism: Comparing Contemporary Europe and Latin America. Government and Opposition 48, 2: $147-74$.

Pelfini, Alejandro. (2011). Global and national political elites in South America: Limited transnationalization processes and the persistence of inequality. In Globalization and inequality inemerging societies, ed. Boike Rehbein. Basingstoke: Palgrave-MacMillan.

Pelfini, Alejandro, (2015). Megatrend Global Populism, dalam Lenger \& Schumacher (eds). Understanding the Dynamics of Global Inequality. New York: Springer.

Stavrakakis, Yanis (2016). Contemporary Left-wing Populism in Latin America: Leadership, Horizontalism, and Postdemocracy in Chávez's Venezuela. Latin American Politics \& Society, Vol. 58 Issue 3, p. 51-76. DOI: 10.1111/j.1548-2456.2016.00318. 